\title{
Peran Public Relations dalam Mempertahankan Reputasi Lembaga Penyiaran Sebagai Media Dakwah
}

\section{Kartika Sari}

STAIN Syaikh Abdurrahman Siddik Bangka Belitung, Indonesia

ti_3k@yahoo.com

\begin{abstract}
Abstrak
Hadirnya lembaga penyiaran dakwah ditengah masyarakat tidaklah hanya berperan sebatas memberikan informasi saja tentang nilai-nilai Islam yang dikemas dengan beragam program acara, namun harapan yang ada adalah bagaimana kehadiran lembaga penyiaran dakwah dapat berimplikasi kepada refleksi perilaku umat muslim yang berperilaku Islami sesuai dengan ajaran Al qur'an dan Hadits. Pihak pengelola lembaga penyiaran harus meyakinkan posisi penting kehadiran mereka di tengah masyarakat (audiensi), yakni dengan memberikan program-program acara yang berkualitas. Tidak sampai di situ saja, hubungan yang baik dengan khalayak dari sebuah lembaga penyiaran pun harus dibina. Hal ini tidak lain agar eksistensi lembaga sebagai media penyampai pesan dakwah tetap didukung keberadaannya agar tetap bertahan di tengah maraknya persaingan. Hubungan ini dapat dibina dengan menjalin komunikasi yang efektif antara lembaga penyiaran dengan khalayak (publik) untuk menghasilkan good image, good will, mutual uderstanding, mutual appreciation, dan tolerance yang dijembatani dengan kehadiran Public Relations (PR)/Humas selaku corong informasi sebuah organisasi penyiaran. Berangkat dari hal tersebut, tulisan ini mengangkat tentang peran Public Relations dalam mempertahankan reputasi lembaga penyiaran sebagai media dakwah.
\end{abstract}

Kata kunci; public relations, reputasi

Received: 11-06-2017; accepted: 16-06-2017; published: 01-07-2017 


\section{A. Pendahuluan}

Informasi adalah bagian dari kebutuhan manusia untuk menunjang aktivitas sehari-hari dalam mempertahankan kehidupannya. Setidaknya, dengan membutuhkan manusia lain menyadarkan bahwa pada dasarnya manusia memiliki keterbatasan. Selain itu, manusia adalah makhluk sosial yang sangat membutuhkan orang lain untuk berdampingan hidup sebagai teman berinteraksi. Dengan adanya informasi yang didapatkan dari media massa dapat membantu manusia dalam hal meningkatkan pengetahuan, membentuk sikap, hingga dapat berperilaku yang merupakan salah satu cara manusia untuk belajar. Hal ini dikarenakan pada kenyataannya manusia tidak dapat mengandalkan informasi tersebut hanya sebatas dari lingkungan sekitar dimana mereka tinggal mengandalkan informasi dari sisi yang terbatas saja. Manusia memerlukan sumber lain yang bisa memperkaya pengetahuan dari informasi yang ada untuk menjaga keberlangsungan hidup, salah satunya melalui media massa.

Dari perkembangan teknologi sekarang justru semakin memudahkan masyarakat untuk mengakses segala informasi dari segala penjuru dunia. Informasi dari media massa salah satunya semakin memperkaya pengetahuan masyarakat, khususnya umat muslim. Misalkan saja, umat muslim dapat belajar tentang nilai-nilai Islam yang dikemas dalam program ceramah, drama, talkshow, dan program acara lainnya dari lembaga penyiaran yang fokus di dunia dakwah. Menurut Bahyul Khully, dakwah adalah memindahkan umat dari satu situasi ke situasi yang lain. ${ }^{1}$ Secara umum, dapat dikatakan bahwa dakwah itu ruang lingkup kerjanya meliputi usaha dan perjuangan merubah situasi yang tidak di ridhoi Allah kepada situasi yang diridhai-Nya. ${ }^{2}$

Pada saat ini, telah banyak channel-channel /lembaga penyiaran stasiun televisi yang memfokuskan untuk menyebarkan ajaran Islam. Ajaran Islam semakin disadari menjadi hal penting untuk dijalankan pedoman hidup karena akan menghadirkan ketentraman, kebahagiaan dunia dan akhirat. Para pemilik media tentunya dapat merasakan bahwa keberadaan mereka sangat penting guna menjadi bagian dari penyebaran dakwah Islam. Dengan kata lain, adanya perkembangan media massa saat ini jelas semakin dapat memperkaya dan membantu umat Islam untuk dapat menjalani roda kehidupan berdasarkan prinsip Islam.

\footnotetext{
${ }^{1}$ Ismail Tunany, Manajemen Pers Dakwah (Jakarta: Graha Guru, 2007), p. 18.

2 Ibid., p. 18.
} 
Media massa adalah produk dari komunikasi massa yang merupakan cara berkomunikasi dengan menggunakan media massa baik cetak, elektronik, maupun menggunakan internet. Posisi media massa saat ini masih terus bertahan dengan semakin berkembang jumlahnya hanya saja dalam menggunakan media massa dikembalikan kepada kebutuhan masyarakat sendiri, yakni media massa mana yang menjadi pilihan mereka untuk ditonton, didengar atau dibaca. Singkat kata, adanya perkembangan media massa harusnya banyak disyukuri kehadirannya karena nilai-nilai Islam justru semakin berkembang dan semakin memiliki posisi dihati masyarakat untuk membantu masyarakat sendiri dalam kehidupannya.

Sasaran pesan komunikasi massa adalah untuk umum. Pesan yang disampaikan adalah seragam dan tidak bersifat pribadi. Dengan penyebaran pesan secara serentak, maka tergambar bahwa pesan yang disampaikan akan diterima secara serempak pula. Harapannya, dapat mempengaruhi perilaku audiensi secara utuh keseluruhan. Keterlibatan manusia dalam menikmati program acara yang disajikan lembaga penyiaran menggambarkan adanya aktivitas interaksi sosial yang dibangun antara kelompok masyarakat dengan kelompok pengelola media massa. Manusia belajar dari manusia dengan manusia lainnya karena ada interaksi sosial di dalamnya, dimana syarat terjadinya interaksi sosial adalah adanya kontak dan komunikasi.

Menurut Hoveland, komunikasi adalah proses dimana individu mentransmisikan stimulus untuk mengubah perilaku individu yang lain ${ }^{3}$. Salah satu faktor mengapa interaksi sosial tersebut terbentuk dikarenakan adanya faktor imitasi /meniru cara-cara yang berlaku di dalam sebuah masyarakat. Tarde yang mengatakan bahwa faktor imitasi merupakan satu-satunya faktor yang mendasari atau melandasi interaksi sosial. ${ }^{4}$ Imitasi tidaklah berlangsung dengan sendirinya. Untuk mengadakan imitasi atau meniru ada faktor psikologis lain yang berperan. Bagaimana orang dapat mengimitasi sesuatu kalau orang yang bersangkutan tidak mempunyai sikap menerima terhadap apa yang diimitasi itu. Dengan demikian untuk mengimitasi seseuatu perlu adanya sikap menerima dan sikap mengagumi terhadap apa yang diimitasi itu. Oleh karena itu, imitasi tidak berlangsung dengan sendirinya. ${ }^{5}$ Berkaitan dengan hal di atas, maka dapat saja pengelola media massa mengemas beragam program acara yang dapat ditiru oleh

\footnotetext{
${ }^{3}$ Wiryanto, Pengantar Ilmu Komunikasi (Jakarta: PT. Gramedia Widiasarana Indonesia, 2004), p .6.

${ }^{4}$ Bimo Walgito, Psikologi Sosial: Suatu Pengantar, Edisi Revisi (Yogyakarta: Andi Yogyakarta, 2003). p, 66.

${ }^{5}$ Ibid., p. 67.
} 
penonton. Misakan saja, apabila pengelola lembaga penyiaran ingin berdakwah maka sudah pasti harus peka dalam mengemas program acara yang bermutu yang memuat nilai-nilai Islami, sehingga mudah ditiru dan bisa berdampak pada kemashalatan ummat.

Cara manusia meniru jelas bermula dari informasi yang didapatkan manusia dari segala macam aspek panca indra yang diantaranya dapat berfungsi untuk mendengar, membaca, dan menonton yang lebih dikenal dengan tahap sensasi. Lalu informasi tersebut dikelola oleh syaraf otak dan ini merupakan tahap pengelolaan yang dikenal dengan persepsi. Informasi tersebut lalu disimpan dalam memori dan suatu saat dapat dipergunakan kembali. Begitupun juga dengan audiens ketika menerima informasi dari media tentunya akan melewati tahap-tahap penerimaan informasi, sehingga dari informasi yang disimpan dapat membentuk terwujudnya suatu perilaku. Harapan ini lah yang sebenarnya ingin diharapakan oleh pengelola media walaupun pada kenyataannya untuk memantau efek dari media yang dikonsumsi punya keterbatasan untuk dijangkau.

Proses menerima informasi tersebut pada akhirnya melahirkan proses imitasi. Proses ini jelas menggambarkan bahwa informasi yang diserap oleh audiensi dapat berdampak pada menimbukan suatu perilaku. Perilaku ditimbulkan oleh seseorang sebagai bentuk reaksi terhadap lingkungan dan dari situ manusia belajar. Apabila informasi tersebut dapat berdampak pada perilaku manusia dari hal ini kita dapat menyimpulkan bagaimana pengaruh pesan media telah menjadi bagian dari internalisasi manusia itu sendiri. Semakin sering manusia menerima informasi apalagi dikuatkan wujud perilaku menunjukkan bahwa nilai-nilai pesan dari suatu media telah berdampak dan diantaranya akan berdampak pada reputasi lembaga penyiaran. Oleh sebab itu, kehadiran komunikasi massa selain sebagai salah satu sumber informasi juga sebagai sarana pewarisan budaya.

Sebenarnya yang menjadi tolak ukur penilaian dari suatu organisasi tentang jati diri suatu organisasi adalah bagaimana reaksi yang dimunculkan oleh khalayak/publik/stakeholeder terhadap suatu organisasi yang merupakan gambaran citra (kesan) dari organisasi tersebut. Apabila kita melihat dari sudut suatu lembaga penyiaran maka penilaian tentang kinerja suatu organisasi tidak hanya sebatas bagaimana program-program acara yang menarik ditayangkan, namun juga bagaimana penilaian-penilaian dari aspek lain dalam suatu organisasi yang akan mempengaruhi 
reputasi dalam suatu organisasi. Reputasi sebenarnya adalah akumulasi dari persepsi dan pendapat tentang organisasi yang berada dalam pikiran stakeholder. ${ }^{6}$ Banyak faktor yang dapat mempengaruhi pembentukan pencitraan suatu organisasi, diantaranya kualitas hasil produk barang /jasa, manajemen administrasi organisasi, identitas fisik serta non fisik, dan pola hubungan dengan publik.

Publik adalah sekelompok orang yang memiliki kepentingan dengan suatu organisasi. Hubungan organisasi dengan kelompok publik harus selalu dibina. Hal ini tidak lain agar dapat menjaga keberlangsungan organisasi itu sendiri. Pola hubungan dengan beragam publik harus direncanakan, harus menyesuaikan kepada siapa komunikan (publik) tersebut dituju, begitu pula dengan pesan yang akan disampaikan dalam bentuk program-progam komunikasi agar keberadaan organisasi dapat selalu didukung dan organisasi dapat mengerti apa yang diinginkan oleh publik. Semua itu akan terjadi jika adanya komunikasi yang pada akhirnya akan menimbulkan saling pengertian dan saling mendukung. Hubungan ini sebenarnya menjadi tanggung jawab semua pihak internal organisasi, namun ada departemen lain yang lebih fokus dalam menjaga hubungan ini yang lebih akrab dikenal dengan istilah Public Relations atau yang lebih akrab populer penyebutannya PR.

Menurut para ahli PR yang tergabung dalam International Public Relations Association, Public Relations adalah fungsi manajemen dari sikap budi yang direncanakan dan dijalankan terus-menerus, yang mana organisasi-organisasi dan lembaga-lembaga yang bersifat umum dan pribadi berusaha memperoleh dan membina pengertian, simpati, dan dukungan dari mereka yang ada sangkut pautnya atau mereka yang diduga akan dengan jalan menilai opini publik di antara mereka dengan tujuan sedapat mungkin menghubungkan kebijaksanaan dan ketatalaksanaan mereka, guna mencapai kerjasama yang lebih produktif dan untuk melaksanakan kepentingan bersama yang lebih efisen dengan jalan penerangan yang berencana dan tersebar luas ${ }^{7}$. Di sisi lain, menurut Scott M. Cutlip, Public Relations adalah fungsi manajemen yang mengidentifikasikan, menetapkan, dan memelihara hubungan yang saling

\footnotetext{
${ }^{6}$ Nova Firsan, Crisis Public Relations: Strategi Menghadapi Krisis, Mengelola Isu, Membangun Citra dan Reputasi Perusahaan. (Jakarta: Rajawali Pers, 2011), p. 309.

7 Rochajat Harun, Komunikasi Organisasi (Bandung: CV Mandar Maju. 2008), pp. 117-8.
} 
menguntungkan antara organisasi dengan segala lapisan masyarakat yang menetukan keberhasilan atau kegagalan public relations. ${ }^{8}$

Sebelum perkembanganya, banyak fungsi PR yang dilakukan oleh divisi lain dalam suatu organisasi. Namun, dalam perkembangannya keberadaan profesi PR dirasakan penting sehingga muncul profesi tersebut dalam beragam jenis organisasi. Hanya saja, strategis atau tidaknya kedudukan PR dalam suatu organisasi adalah tidak lepas dari bagaimana pimpinan menilai fungsi PR itu sendiri. PR lah yang menjadi mediator dalam menyampaikan informasi organisasi dan fasilitator dalam hubungan pihak organisasi dengan publiknya.

Perbedaan orientasi fungsi dan pekerjaan tersebut minimal membawa dua konsekuensi. Pertama, pada penempatan PR di struktur organisasi/institusi. PR yang melaksanakan fungsi manajemen strategis telah menduduki posisi dekat dengan penentu kebijakan dalam struktur piramida organisasi/institusi. Sementara PR yang menerapkan pekerjaan teknis semata menunjukkan sebaliknya. Kedua, pada tujuan pelaksanaan fungsi PR. Pada PR yang menjalankan fungsi manajemen secara umum melaksanakan komunikasi dua arah simetrik, sedangkan PR yang melaksanakan tugastugas teknis cenderung sistem komunikasi satu arah atau dua arah asimterik dalam setiap kebijakannya. ${ }^{9}$

Seperti yang telah dipaparkan di atas, menciptakan pencitraan yang baik adalah hal yang sangat penting untuk mempertahankan keberadaan suatu organisasi. Adalah menjadi fungsi utama PR dalam suatu organisasi untuk menciptakan dan mempertahankan suatu organisasi ke arah yang lebih baik. Akumulasinya dari pencitraan adalah sebuah reputasi yang harus dijaga dan dipertahankan oleh organisasi. Untuk menciptakan ini semua tentunya memerlukan proses waktu. Begitupun juga dengan lembaga penyiaran kesan yang baik ataupun sebaliknya akan mempengaruhi nama baik lembaga itu sendiri. Kesan yang baik tersebut harus diprogramkan oleh pihak manajemen lembaga penyiaran dakwah. Karena apabila lembaga penyiaran dalam pencitraannya sudah memiliki posisi bagi audiensi maka operasional perusahaan tetap berjalan. Apalagi jika lembaga ini berorientasi profit maka lembaga penyiaran akan memiliki banyak keuntungan program dan diminati audiens sehingga pengiklan pun

\footnotetext{
8 Ibid., p. 118.

9 Felix, Jebarus \& Muslim, Basya, Standar Kompetensi Menuju Humas Professional (Jakarta: Lembaga Sertifikasi Profesi, 2013), p. 31.
} 
banyak yang mengiklankan produknya dan menyebabkan keuntungan bagi pihak media. Pengelola media jelas harus mempertimbangkan hal ini karena kualitas layanan secara keseluruhan mempengaruhi pembentukan citra.

Apalagi pengelola lembaga penyiaran yang memiliki visi menyuarakan dakwah Islam jelas harus memberikan pelayanan terbaik agar tidak dianggap memberikan pesan yang sesat. Menyuarakan kebenaran yang akan menolong kehidupan yang jika diniatkan untuk Allah SWT, maka akan bahagia dunia akhirat. Lembaga penyiaran adalah bentuk dari organisasi yang menghasilkan produk layanan jasa informasi yakni bidang jasa yang memberikan pesan-pesan dalam bidang informasi guna tujuan mendidik, memberi informasi, dan dapat juga membentuk suatu kebudayaan bagi audiensi. Dengan adanya lembaga penyiaran yang berorientasi dakwah, sangat diharapkan kehadirannya untuk menjadi sarana pengubah kehidupan umat Islam menjadi lebih baik. Untuk meyakinkan audiensi bahwa lembaga penyiaran adalah lembaga yang berdayaguna dalam kehadirannya di tengah masyarakat apalagi dengan tujuannya berdakwah, maka sudah sepatutnya bagi penyelenggara jasa informasi ini untuk memberikan kontribusi yang dapat mencerahkan umat.

Nilai kepercayaan sebuah media dakwah sangat penting maka harus dibangun dengan memberikan pesan-pesan yang dapat meningkatkan hubungan antara organisasi dengan publik sehingga keberadaan organisasi selalu didukung keberadaannya. Kepercayaan atau trust adalah modal penting agar media penyiaran selalu didukung. Para pemilik dan pengelola lembaga penyiaran adalah sosok komunikator. Komunikator adalah pihak pertama yang berinisiatif memulai untuk berkomunikasi. Komunikator merupakan salah satu faktor yang ikut menentukan efektif atau tidaknya suatu pesan komunikasi. Komunikator dalam lembaga penyiaran sifatnya adalah melembaga terdiri dari kelompok orang diantaranya ada yang menjadi pemimpin media, repoter, PR/humas, bagian security, dan bidang lainnya yang saling berinteraksi untuk kekuatan sebuah sistem yakni lembaga penyiaran itu sendiri.

Di dalam lembaga penyiaran dakwah, humas harus bisa menjembatani hubungan antara publik internal di dalam organisasi maupun publik eksternal diluar organisasi. Publik adalah kelompok orang intern dan ekstern yang dengan kelompok-kelompok tersebut suatu organisasi berkomunikasi. ${ }^{10}$ Ini adalah gambaran dinamika dalam suatu

10 Frank Jefkins, Hubungan Masyarakat, terj. A Muchlis Alimin (Jakarta: PT Intermasa, 1992), p. 39. 
organisasi. Peran PR dituntun di sini salah satunya adalah mempertahankan nama baik suatu organisasi. PR berperan dalam menjaga hubungan/relationship antara pihak organisasi baik ke pihak internal maupun pihak eksternal perusahaan melalui programprogram komunikasi guna menjaga kestabilan hubungan komunikasi. Menjaga suatu hubungan adalah hal yang penting karena akan memperkuat suatu hubungan antara organisasi dengn publiknya.

Lembaga penyiaran dalam keberadaannya di tengah masyarakat harus memiliki posisi aman. Dengan kata lain, harus didukung keberadaannya dan lembaga penyiaran pun harus mengetahui bahwa untuk mendapatkan semua itu perlu didukung oleh suatu hubungan yang dibangun dalam suatu hubungan yang baik, berkesinambungan agar memperoleh saling kepercayaan walaupun diantara pola manajemen organisasi media terdiri dari dua kepemimpinan yakni pemimpin perusahaan dan pemimpin yang khusus menjadi pemimpin bagian redaksi. Karena lembaga penyiaran adalah suatu organisasi maka kedua pemimpin dalam manajemen tersebut harus saling mendukung guna menjaga keberlangsungan suatu organisasi. Kehadiran lembaga penyiaran dakwah dinilai memiliki peran yang mulia untuk dapat menyuarakan nilai-nilai Islam.

Publik tentunya menaruh banyak harapan bagaimana lembaga penyiaran ini dapat memberikan manfaat atau berdaya guna bagi masyarakat khususnya bagi umat Islam. Posisi PR sangat penting disini saling bersinergi dengan semua sub sistem lainnya dalam suatu organisasi untuk menciptkan hubungan yang harmonis antara organisasi dengan pihak internal maupun pihak eksternal. Berdasarkan pemaparan di atas, maka menarik bagi penulis untuk mengkaji Peran Public Relations dalam Mempertahankan Reputasi Lembaga Penyiaran sebagai Media Dakwah.

\section{B. Tentang Massa dan Komunikasi Massa}

Komunikasi massa dapat terbentuk karena ada kebutuhan dari masyarakat untuk mendapatkan informasi dari berbagai macam sumber pesan yang tidak hanya didapatkan dari satu sumber, namun sumber lainnya yang tersebar luas bahkan sampai ke penjuru dunia. Hal ini tentunya akan membentuk komunikasi massa. Menurut Gustave Le Bon, massa merupakan suatu kumpulan orang banyak, berjumlah ratusan 
atau ribuan, yang berkumpul dan mengadakan hubungan untuk sementara waktu, karena minat dan kepentingan bersama yang sementara pula. ${ }^{11}$

Massa memiliki unsur-unsur penting yakni :

1. Terdiri dari masyarakat dalam jumlah yang besar (large aggregate). Massa terdiri dari jumlah masyarakat yang sangat besar yang menyebar dimana-mana, dimana satu dengan lainnya tidak saling tahu-menahu bahkan tidak pernah bertemu dan berhubungan secara personal

2. Jumlah massa yang besar menyebabkan massa tidak bisa dibedakan satu dengan lain nya (undifferentiated). Sulit dibedakan mana anggota massa satu dengan lainnya di suatu masyarakat karena jumlahnya yang besar itu.

3. Sebagian besar anggota massa memiliki negatif image terhadap pemeberitaan media massa. Massa senantiasa mencurigai pemeberitaan media massa sebagai sesuatu yang benar, bahkan untuk hal-hal tertentu cenderung skepstis dan berfikir negatif.

4. Karena jumlah yang besar, maka massa juga sukar diorganisir. Jumlah massa yang besar itu maka massa cenderung bergerak sendiri-sendiri berdasarkan sel-sel massa yang dapt dikendalikan oleh orang-orang dalam sel itu.

5. Massa merupakan refleksi dari kehidupan sosial secara luas. Setiap bentuk kehidupan sosial yang ada dalam sebuah masyarakat adalah refleksi dari kondisi sosial masyarakat itu sendiri, begitu pula dengan massa adalah refleksi dari keadaan sosial masyarakat secara keseluruhan. ${ }^{12}$

Sedangkan audiens massa memiliki ciri yakni:

1. Terdiri dari jumlah besar. Pendengar radio, televisi atau pembaca koran adalah massa dalam jumlah yang besar.

2. Suara pemberitaan media massa dapat ditangkap oleh masyarakat dari berbagai tempat, sehingga sifat audiens massa juga ada tersebar di mana-mana, terpencar, dan tidak mengelompokan pada wilayah tertentu.

3. Pada mulanya audiens massa tidak interaktif, artinya antara media massa dan pendengar atau pemirsanya tidak saling berhubungan. Namun saat ini konsep ini

\footnotetext{
11 Ibid., p. 117.

12 Burhan Bungin, Sosiologi Komunikasi: Teori, Paradigma, dan Diskursus Teknologi Komunikasi di Masyarakat (Jakarta: Kencana Prenada Media Group, 2006), pp. 73-4.
} 
mulai ditinggal, karena audiens massa dan media massa dapat berinteraksi satu dengan lainnya melalui komunikasi telepon.

4. Terdiri dari berbagai lapisan masyarakat yang sangat heterogen. Audiensi massa tidak dapat dikategorikan terdiri dari segmentasi tertentu, kalaupun ada seperti dalam acara-cara televisi dan radio maupun media cetak, maka heterogenitas dalam segmen tersebut tidak dapat dihindari.

5. Tidak terorganisir dan bergerak sendiri. Karena sifatnya yang besar, maka audiensi massa sulit diorganisir dan akhirnya bergerak sendiri-sendiri. ${ }^{13}$

Berangkat dari teori di atas, lembaga penyiaran dakwah jelas memiliki jumlah penonton yang banyak jumlahnya, tidak terbatas dan tersebar luas bahkan sampai kesegala pelosok dunia yang bisa saja tidak terjangkau bagi komunikator (pengelola media) yang memberikan informasi tersebut. Karena luasnya dan heterogenitasnya jumlah audiensi maka hal ini dapat saja disikapi oleh pengelola media justru untuk dapat menayangkan berbagai pilihan program acara yang dapat mengena ke dalam berbagai lapisan dan kelompok sosial masyarakat. Hal ini patut disyukuri oeh pengelola media karena semakin memperluas jangkauan penyebaran nilai-nilai dakwah itu sendiri. Pengelola media dapat menyesuaikan dengan menayangkan program-program acara sesuai dengan karakteristik segmen audiensi yang dituju misalkan dari sisi demografik, gaya hidup maupun geografik para audiensi yang mudah saja menyentuh kelompok sosial tersebut apalagi dengan adanya kemajuan teknologi yang sudah dapat dirasakan keberadaannya.

Adapun keberadaan komunikasi massa ditengah masyarakat memiliki fungsi yakni:

1. Fungsi pengawasan: media massa merupakan sebuah medium dimana dapat digunakan untuk pengawasan terhadap aktivitas masyarakat pada umumnya. Pengawasan dan kontrol sosial dapat dilakukan untuk aktivitas preventif untuk mencegah terjadinya hal-hal yang tidak diinginkan.

2. Fungsi social learning: fungsi ini didapatkan dari media massa adalah melakukan guiding dan pendidikan sosial kepada masyarakat. Media massa bertugas untuk memberikan pencerahan-pencerahan kepada masyarakat dimana komunikasi massa itu berlangsung.

13 Ibid., pp. 75-7. 
3. Fungsi penyampaian informasi: komunikasi massa yang mengandalkan media massa, memiliki fungsi utama yatu menjadi proses penyampaian informasi kepada masyarakat luas.

4. Fungsi transformasi budaya: komunikasi massa lewat media massa menjadi proses transformasi budaya yang dilakukan bersama-sama oleh semua komponen komunikasi massa, terutama yang didukung oleh media massa.

5. Fungsi hiburan: komunikasi massa juga digunakan sebagai medium hiburan, terutama karena komunikasi massa menggunakan media massa. Jadi fungsi-fungsi hiburan yang ada pada media massa juga merupakan bagian dari fungsi komunikasi massa. $^{14}$

Lembaga penyiaran dakwah harus bisa menerapkan fungsi-fungsi tersebut, yakni bagaimana kehadiran mereka di tengah umat muslim dengan format program-program acara yang disiarkan memiliki nilai sebagai sarana untuk mendidik audiensi untuk berperilaku berdasarkan prinsip Islam. Hal ini untuk menambah wacana pengetahuan umat muslim. Dari tujuan menginformasikan untuk dapat mendidik pada akhirnya bagaimana pengaruh dari pesan komunikasi massa ini dapat menjadi bagian kehidupan audiensi, menjadi kebiasaan yang pada akhirnya dapat membentuk kebudayaan. Pola ini jelas menggambarkan terbentuknya fungsi transformasi budaya. Tidak hanya sebatas itu, bagaimana fungsi dari lembaga penyiaran dapat memberikan hiburan bagi audiensi yang sedang menonton atau mendengar. Ada rasa kebahagiaan, ketenangan, dan keceriaan yang dirasakan oleh audiensi setelah menggunakan media tersebut.

Mc Quail menambahkan proses komunikasi massa terlihat berproses dalam bentuk:

1. Melakukan distribusi dan penerimaan informasi dalam skala besar. Jadi proses komunikasi massa melakukan distribusi informasi kemasyarakatan dalam skala yang besar, sekali siaran, pemberitaan yang disebarkan dalam jumlah yang luas dan diterima oleh massa yang besar pula.

2. Proses komunikasi massa juga dilakukan melalui satu arah, yaitu dari komunikator ke komunikan. Kalau terjadi interaktif diantara mereka, maka proses komunikasi (balik) yang disampaikan oleh komunikan ke komunikator sifatnya sangat terbatas, sehingga tetap saja didominasi oleh komunikator.

14 Ibid., pp. 79-81. 
3. Proses komunikasi massa berlangsung secara asimetris diantara komunikator dan komunikan menyebabkan komunikasi diantara mereka berlangsung datar dan bersifat sementara.

4. Proses komunikasi massa juga berlangsung impersona (non pribadi) dan tanpa nama. Proses komunikasi massa juga berlangsung berdasarkan pada hubunganhubungan kebutuhan market di masyarakat.15

\section{Reputasi Perusahaan}

Menjaga reputasi perusahaan sama artinya dengan menjaga keberlangsungan suatu organisasi. Hal ini sangat penting bagi organisasi, persepsi audiensi sangat berperan dalam mempengaruhi keberlangsungan suatu organisasi. Eksistensi suatu organisasi adalah tidak lepas dari kesadaran suatu organisasi bahwa publik adalah kelompok yang sangat penting keberadaannya utuk diperhatikan. Oleh karena itu, hal ini harus segera disadari oleh perusahaan khususnya para pemimpin perusahaan bahwa peran dari seorang pemimpin perusahaan sangatlah penting untuk mengkoordinir segala macam program kerja untuk mempertahankan organisasi.

Reputasi lembaga penyiaran sebenarnya adalah penilaian akhir dalam suatu organisasi. Memang pada dasarnya reputasi adalah aset perusahaan yang abstrak, bersifat non fisik yang tidak dapat dilihat namun dapat dirasakan ruhnya untuk kestabilan sebuah organisasi. Menciptakan reputasi yang baik bukanlah hal yang mudah, memerlukan waktu dalam pengelolaannya. Reputasi yang baik maka akan dinilai baik pun sebaliknya reputasi yang buruk akan dinilai buruk juga. Sekali lagi dalam pembentukkan reputasi positif organisasi tidaklah semudah membalikkan tangan. Tentunya akan melewati banyak proses. Proses ini tidak lepas dari bagaimana publik merasakan pelayanan yang diberikan lembaga penyiaran. Dalam pelaksanaannya harus tetap bisa membangun hubungan / relationship, mengerti hal apa yang diinginkan oleh organisasi begitupun yang diinginkan publik. Jika reputasi perusahaan tersebut tidak dijaga maka pada akhirnya akan mengancam keberdaan organisasi itu sendiri.

15 Ibid., pp. 74-5. 
Berikut dasar pembentukan reputasi organisasi: ${ }^{16}$

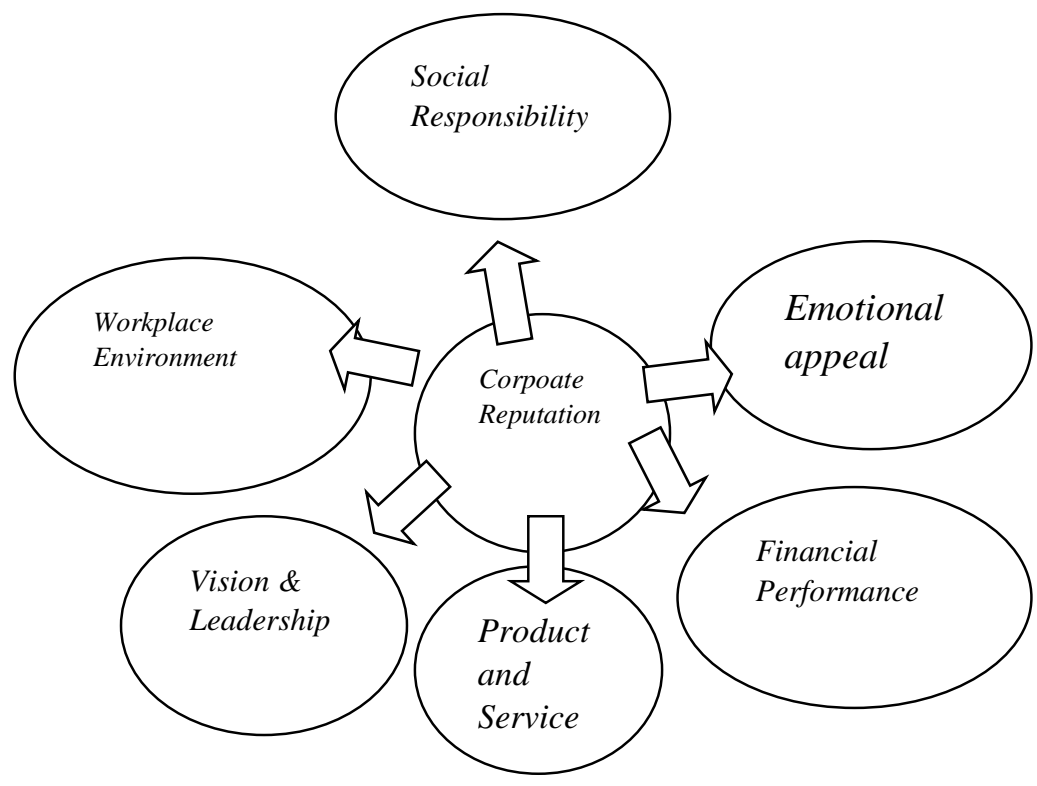

Selain itu ditambahkan lagi ada beberapa faktor yang menjadi dasar pembentukan reputasi adalah:

1. Komunikasi. Robert D Ross mengatakan bahwa komunikasi merupakan kegiatan yang penting bagi perusahaan dalam membangun reputasi atau citra positif dimata publiknya. Dengan kata lain bahwa fungsi PR salah satunya adalah melakukan fungsi-fungsi manajmen komunikasi antara organisasi atau lembaga yang diwakilinya dengan publik sebagai khalayak sasarannya.

2. Sikap Profesional. Profesionalisme adalah cara bekerja yang sangat didominasi oleh sikap, bukan hanya sekadar daftar dari skill dan kompetensi yang dimiliki.

3. Kepercayaan Publik. Reputasi bisa dibangun dengan menumbuhkan kepercayaan dan kepuasan publik lewat pengalaman, pencapaian atau realisasi janji-janji yang telah ditetapkan. Di sini perlu adanya keselarasan antara ucapan dan tindakan serta keterbukaan dalam informasi dan komunikasi. Kepercayaan publik adalah keyakinan (belief) yang dibangkitkan dalam masyarakat atas keputusan yang diambil dan keberlanjutan terhadap suatu entitas tertentu.

4. Inovasi produk. Terus berinovasi menciptakan produk atau layanan terbaru menunjukkan bahwa sebuah perusahaan ingin maju dalam bidangnya dan peduli dengan kebutuhan masyarakat. Ada beberapa hal penting terkait inovasi dari

16 Nova Firsan, Crisis Public Relation, p. 314. 
para pebisnis yakni: pertama, inovasi sangat berperan dalam kelangsungan hidup perusahaan; kedua, kepedulian perusahaan pada inovasi haruslah tinggi; ketiga, perlu adanya penghargaan kepada industri yang mengembangkan inovasi; keempat, inovasi dapat mendongkrak citra perusahaaan dan daya saing perusahaan; kelima, inovasi mendukung strategi pemasaran dan public relations; keenam, membuat perusaahaan mampu menciptakan pasar ceruk baru; ketujuh, meningkatkan penjualan dan ke delapan perlu mematenkan inovasi yang mereka lakukan.

5. Tanggung jawab Sosial. Kepedulian sosial perusahaan terutama didasari alasan bahwasanya kegiatan perusahaan membawa dampak, for better or worse bagi kondisi lingkungan dan sosial ekonomi masyarakat, khususnya di sekitar dimana perusahan beroperasi. Melalui program CSR, reputasi atau citra perusahaan dapat terdongkrak dimata publiknya. Karena dengan program tersebut masyarakat bisa merasakan manfaat dari keberadaan perusahan tesebut.

6. Kualitas layanan Konsumen. Kualitas layanan yang baik bukanlah berdasarkan persepsi penyedia jasa/produk melainkan berdasarkan persepsi konsumen. Yang kualitas layanan konsumen itu dapat dilihat dari sudut tangible berupa desain gedung, seragam karyawan, kebersihan peralatan yang digunakan, dan fasilitas fisik lainnya. Reliability yakni dimensi yang mengukur kehandalan dari perusahaan dalam memberikan pelayanan kepada pelanggannya sesuai dengan janji yang disampaikan dalam komunikasi pemasaranya. Responsiveness adalah sejauh mana perusahaan tanggap dalam melihat kebutuhan dan keinginan pasar. Harapan pelanggan terhadap kecepatan pelayanan hampir dapat dipastikan akan berubah dengan kecenderungan naik dari waktu ke waktu. Assurance adalah dimensi kualitas yang berhubungan dengan kemampuan perusahaan dan perilaku front line staf dalam menanmkan rasa percaya dan keyakinan kepada para pelanggannya. Emphaty adalah bagaimana memperlakukan konsumen sebagai individu.

7. Responsif terhadap feedback publik. Responsif terhadap feedback publik merupakan upaya perusahaan untuk peduli terhadap para pelanggannya, baik memberikan layanan terbaik maupun menjawab segala keluhan pelanggan. 
Lembaga penyiaran dakwah harus menyadari bahwa banyak faktor yang menyebabkan terbentuknya reputasi. Faktor memberikan pelayanan secara umum yang terbaik bagi umat Islam jelas akan menaikkan reputasi, diantaranya bagaimana pengelola media dapat memberikan program-program acara yang merupakan produk dari lembaga penyiaran yang dapat menjawab kebutuhan umat muslim sehingga dapat memberikan pencerahan. Membuat materi acara yang dapat menjawab segala isu yang menjadi persoalan umat muslim dan dalam hal ini tuntutan menjadi seorang jurnalis yang profesional berjiwa islami sangat diperlukan. Program-program acara yang inovatif yang memiliki daya saing tentu akan memiliki posisi tawar diantara pesaing lainnya. Namun yang paling penting adalah bagaimana muatan program acara yang sesuai dengan misi visi dakwah demi menjaga nama baik organisasi untuk tujuan berdakwah.

Selain itu hal lain yang harus diperhatikan adalah menciptakan lingkungan kerja yang kondusif yang akan membentuk pencitraan. Pola hubungan yang harmonis melalui komunikasi yang dibina antara organisasi dengan publiknya pun juga akan membentuk sisi lain pencitraan lembaga penyiaran dakwah. Dari hasil komunikasi tersebut akan menghasilkan informasi sebut saja diantaranya dapat menjadi masukkan bagi pihak media untuk membuat program acara yang sesuai dengan keinginan publik. PR dalam hal ini yang menjembatani hubungan tersebut harus peka mengetahui apa yang diinginkan oleh publik.

PR tentunya harus menyesuaikan dengan siapa mereka berkomunikasi khususnya bagi kelompok publik yang memiliki kaitan dekat dengan organisasi yang diwakilinya. Dengan mengetahui siapa saja kelompok publik (komunikan) tersebut maka akan memudahkan untuk menentukan pendekatan komunikasi yang digunakan. Sebut saja diantara beberapa publik lembaga penyiaran baik internal ataupun eksternal adalah karyawan, keluarga karyawan, pemegang saham, pihak pengelola production house, lembaga pemberitaan, kontributor, penonton/pendengar (masyarakat luas), serta masyarakat sekitar.

Kehadiran kelompok publik ini jelas akan mempengaruhi keberlangsungan organisasi itu sendiri. Seperti yang sudah dipaparkan di atas maka pola-pola komunikasi harus dibentuk sesuai dengan kelompok publik yang menunjukkan rasa menghargai. Toleransi organisasi kepada publik diantaranya dengan membuat program acara yang 
ditayangkan misalkan dalam bentuk sinetron, ceramah ataupun aktivitas komunikasi langsung melalui program-program komunikasi, misalkan dalam bentuk tanggung jawab sosial kepada masyarakat. Lembaga penyiaran dalam hal ini membuat program tahunan Corporate Social Responsibility (CSR) untuk memberikan bantuan kepada masyarakat sekitar berdirinya organisasi atau pun kelompok masyarakat lain yang menunjukkan kepedulian organisasi. Jelas hal ini akan meningkatkan reputasi yang baik tentang organisasi.

Berikut cara perusahan untuk secara optimal merespons masukan masyarakat:

1. Sensitif terhadap perkembangan produk dipasar dan perkembangan citra perusahaan di mata masyarakat.

2. Merespon dengan segala keluhan dan masukan dari masyarakat.

3. Berikan informasi atau respon tersebut dengan kata-kata sederhana dan mudah dipahami oleh pelanggan.

4. Menawarkan insentif untuk mendorong konsumen memberikan keluhan atau saran. Banyak perusahaan menawarkan insentif bagi para pelanggan yang memberikan kritik dan sarannya bagi produk.

5. Menyediakan layanan 1x24 jam untuk melayanai masyarakat seperti call center. Tepati janji kita ingin menjawab respon tersebut seperti surat pembaca, jawaban tidak boleh lewat dari 2x24 jam. Keterlambatan dalam merespon akan berakibat perusahaan dinilai tidak peduli terhadap keluhan publik. ${ }^{17}$

\section{Kompetensi Public Relations sebagai Corong Informasi}

Public Relations merupakan suatu profesi yang strategis dalam mendukung eksistensi suatu organisasi. Oleh karena itu keberadaannya harus didukung. Berikut beberapa kompetensi yang harus dimiliki oleh humas dalam menjalankan profesinya. Secara estimologi kompetensi diartikan sebagai kemampuan yang dibutuhkan untuk melakukan atau melaksanakan pekerjaan yang dilandasi oleh pengetahuan, keterampilan, dan sikap kerja. Dengan dikuasainya standar kompetensi tersebut oleh seseorang maka yang bersangkutan akan mampu dalam:

1. Mengerjakan suatu tugas atau pekerjaan.

2. Mengorganisasikannya agar pekerjaan tersebut dapat dilaksanakan.

${ }^{17}$ Nova Firsan. Crisis Public Relations, pp. 314-22. 
3. Melakukan bilamana terjadi sesuatu yang berbeda dengan rencana semula.

4. Menggunakan kemampuan yang dimilikinya untuk memecahkan masalah atau melaksanakan tugas dengan kondisi yang berbeda ${ }^{18}$

Kompetensi ini muncul karena PR memiliki peran dalam pekerjaannya yakni:

1. Upaya yang terencana dan terorganisasi dari sebuah perusahaan atau lembaga untuk menciptakan hubungan-hubungan yang saling bermanfaat dengan berbagai publiknya.

2. Pada dasarnya PR adalah:

a) Kegiatan yang bertujuan memperoleh good will, kepercayaan, saling adanya pengertian dan citra yang baik dari publik atau masyarakat pada umumnya.

b) Memiliki sasaran untuk menciptakan opini publik yang bisa diterima dan menguntungkan semua pihak.

c) Unsur penting dalam manajemen guna mencapai tujuan yang spesifik, sesuai harapan publik, tetapi merupakan kekhasan organisasi/perusahaan.

d) Usaha menciptakan hubungan yang harmonis antara organisasi atau perusahaan dengan publiknya internal atau eksternal melalui proses timbal balik, sekaligus menciptakan opini publik sebagai efeknya yang sangat berguna sebagai input bagi organisasi/perusahaan yang bersangkutan

3. Kegiatan PR haruslah dilakukan secara menyeluruh dan berkesinambungan.

4. Sukses PR dalam melaksnakan fungsinya. Merupakan keterlibatan seluruh individu dalam organisasi, masing-masing dalam tugasnya, mulai dari top dan staff management sampai tingkat yang paling bawah dalam manajemen.

5. PR haruslah dimulai dari masing-masing organisasi dan organisasi itu sendiri. ${ }^{19}$ Dari paparan hal di atas kita dapat menyimpulkan bahwa bagaimana keberadaan PR dalam sebuah lembaga penyiaran dakwah adalah membuat manajemen komunikasi dengan berbagai macam publik organisasi. Manajemen komunikasi untuk mengatur hubungan dengan berbagai publik yang terus dibina dari waktu ke waktu untuk menjaga nama baik dari lembaga penyiaran.

\footnotetext{
18 Ibid., p. 35.

19 Maria Assumpta Romanti, Dasar-Dasar Public Relations: Teori dan Praktik (Jakarta: PT Gramedia, 2005), pp. 32-3.
} 


\section{E. PR dalam Mempertahankan Reputasi Lembaga Penyiaran sebagai Media Dakwah}

Saat ini pada perkembangannya keberadaan media massa khususnya lembaga penyiaran dakwah semakin beragam sebut saja diantaranya Insan TV, Rodja TV, Aswaja TV, TV MU, MNC Muslim, Islamic TV, dan MQ TV. Lembaga penyiaran yang semakin beragam ini jelas menunjukkan bahwa semakin sayap dakwah tidak hanya sekadar dibatasi diatas mimbar, namun telah meluas, mengenai seluruh lapisan masyarakat muslim di dunia.

Lembaga penyiaran adalah organisasi sedangkan Public Relations (PR) adalah salah satu pihak yang menggerakkan organisasi.PR dan unsur internal organisasi lainnya adalah komunikator dari suatu organisasi. Keberadaan Public Relations selaku sosok komunikator diharapkan dapat memberi pengaruh bagi keharmonisan hubungan organisasi dengan publiknya. Kehadiran PR ini dianggap memiliki nilai yang dapat menjaga hubungan antara organisasi dengan publiknya. Untuk menjadi komunikator seorang PR harus profesional dalam menjalankan perannya. Seperti kita ketahui produk dari lembaga penyiaran adalah berupa layanan informasi. Informasi yang dikemas dengan beragam acara adalah menggambarkan karakteristik dari lembaga penyiaran itu sendiri. Selaku pengelola media dakwah maka tentunya perilaku yang ditunjukkan kedalam publik adalah perilaku muslim yang dapat dikemas dalam beragam program acara dan hubungan sosial yang baik dengan publik organisasi. Banyaknya program acara yang dikemas dan tidak memberikan nilai kepada masayarakt bisa saja menyebabkan hancurnya reputasi suatu lembaga penyiaran.

Kita dapat melihat beberapa kasus yang menyeret nama beberapa stasiun TV yang bermasalah sehingga menyebabkan munculnya aduan masyarakat jelas tidak bisa dianggap remeh oleh suatu organisasi, apalagi jika nama tersebut disebarluaskan oleh sumber lain atau menjadi bahan pembicaraan dikalangan masyarakat. Oleh sebab itu organisasi dalam hal ini khususnya bagian PR harus cepat tanggap menanggapi hal tersebut sehingga jangan sampai mencoreng nama lembaga penyiaran. Adanya aduan dari masyarakat selaku audiens dapat menyebabkan rating program menjadi turun, dan media tersebut harus siap jika audiens beralih ke channel lain yang dianggap memiliki program acara yang lebih mencerahkan, yang memiliki nilai dimata masyarakat. Jika 
seringnya banyak aduan dari masyarakat akan membuat program acara tersebut ditutup, menutup akses pengiklan, dan berpengaruh pada reputasi dan eksistensi organisasi.

Lembaga penyiaran dakwah pada dasarnya adalah sama dengan lembaga lainnya yang sama-sama kehadirannya ditengah masyarakat untuk memberikan warna. Salah satu warna yang diberikan adalah untuk menyebarkan dakwah Islam. Hal ini tentunya harus kita sambut dengan baik apalagi dengan tujuan semakin memperkuat kedudukan Islam, namun dengan syarat lembaga penyiaran dakwah itu harus dikelola secara profesional dan bernilai Islami untuk menjaga hubungan baik dengan publik yang akan berdampak pada reputasi organisasi yang akan sehingga keberlangsungan organisasi media dakwah tetap terjaga ditengah masyarakat.

\section{F. Penutup}

Pada dasarnya mempertahankan reputasi lembaga penyiaran tidaklah hanya sebatas dilihat dari program-program acara yang diminati audiens saja, namun lebih dari itu yakni bagaimana menjaga hubungan yang baik. Public Relations adalah sebuah profesi yang jika disadari keberadaannya bagi pimpinan organisasi adalah hal yang sangat penting kedudukannya dalam menjaga nama baik organisasi.

PR memiliki posisi yang sangat strategis dalam menentukan keberlangsungan suatu organisasi karena mereka adalah sumber informasi. Keberadaan mereka adalah untuk menjual reputasi organisasi melalui pendekatan komunikasi. Namun di sisi lain semua tanggungjawab itu bukanlah semata hanya pekerjaan PR saja, juga semua elemen internal dalam organisasi itu sendiri yang harus saling mendukung dan menguatkan. Untuk menguatkan hubungan tersebut, maka perlu dibina dengan komunikasi. Jika organisasi ini tetap dijaga maka lembaga penyiaran dakwah pun tetap bertahan dan nilai Islam pun tetap terjaga di bumi Allah. 


\section{DAFTAR PUSTAKA}

Bungin, Burhan. Sosiologi Komunikasi (Teori, Paradigma dan Diskursus Teknologi Komunikasi di Masyarakat). Jakarta: Kencana Prenada Media Group, 2006.

Basya, Muslim dan Jebarus, Felix. Standar Kompetensi Menuju Humas Professional. Jakarta: Lembaga Sertifikasi Profesi, 2013.

Harun, Rochajat. Komunikasi Organisasi. Bandung: CV Mandar Maju. 2008.

Jefkins, Frank. Hubungan Masyarakat, terj. A Muchlis Alimin. Jakarta: PT Intermasa, 1992.

Nova, Firsan. Crisis Public Relations (Strategi Menghadapi Krisis, Mengelola Isu, Membangun Citra dan Reputasi Perusahaan). Rajawali Pers, 2011.

Romanti, Assumpta, Maria. Dasar-Dasar Public Relations Teori dan Praktik, Jakarta: PT Gramedia, 2005

Walgito, Bimo. Psikologi Sosial (Suatu Pengantar) Edisi Revisi. Yogyakarta: Andi Yogyakarta, 2003.

Wiryanto, Pengantar Ilmu Komunikasi. Jakarta: PT. Gramedia Widiasarana Indonesia, 2004. 